\title{
Legal Formalism and the Red-Hot Knife
}

\author{
Daniel A. Farber $\dagger$
}

My title is from a story told in Isak Dinesen's Out of Africa. ${ }^{1}$ It recounts a conversation about the Merchant of Venice with a Somali man named Farah. As you recall, Shylock was cheated of his pound of flesh because of a Venetian law against "shedding the blood" of a citizen. Farah felt that this was an injustice, and an avoidable one:

"What?" said he. "Did the Jew give up his claim? He should not have done that. The flesh was due to him, it was little enough for him to get for all that money."

"But what else could he do," I asked, "when he must not take one drop of blood?"

"Memsahib," said Farah, "he could have used a red-hot knife. That brings out no blood."

Lest we dismiss Farah as a product of a so-called "primitive legal culture," we would do well to keep in mind similarly literalist arguments by modern judges, ${ }^{3}$ some of whom seem equally unwilling to look behind a statute's words to its purpose. ${ }^{4}$ Indeed, in their contributions to this Symposium, Larry Alexander and Leo Katz insist that formalism's essence is precisely this refusal

$\dagger$ Henry J. Fletcher Professor of Law and Associate Dean for Research and Faculty, University of Minnesota. Thanks are due to Jim Chen, Dianne Farber, and Suzanna Sherry for helpful comments.

1 Isak Dinesen, Out of Africa (Modern Library 1992) (1st ed 1937).

2 Id at 267-68. I wish I could take credit for independently discovering this wonderful story, but I found it in Richard A. Posner, Law and Literature: A Misunderstood Relation 96-97 n 38 (Harvard 1988).

3 Consider, for example, the defendant who went from bank to bank withdrawing $\$ 9,999$ in cash in order to cover a gambling debt. He adopted this strategy for the specific purpose of evading a federal law requiring banks to report any transaction involving $\$ 10,000$ in cash. Although the statute prohibited "structuring" transactions to evade the reporting requirement, the Court held that the government had to prove not only that he was deliberately evading the reporting requirement but also that he knew that evasion was specifically prohibited by the statute. Ratzlaf v United States, 510 US 135, 149 (1994).

- For instance, in arguing that the Endangered Species Act prohibits killing animals but not extinguishing the species by preventing it from breeding, Justice Scalia railed against the majority's reliance on the broad purpose of the statute. Babbitt $v$ Sweet Home Chapter of Communities for a Great Oregon, 515 US 687, 721-25 (1995) (Scalia dissenting). 
to look beyond the letter of the law to its spirit or purpose. ${ }^{5}$ Both of them seemingly recognize that formalism, so conceived, has genuine moral costs.

Despite some quarrels with their arguments, I believe that this general conclusion is sound. Formalism does indeed carry potentially serious moral costs, by requiring injustice in a particular case because strict adherence to a rule will have beneficial consequences in other cases. Thus with formalism necessarily comes, in the end, the willingness on occasion to countenance Farah's red-hot knife. This is not an argument for the wholesale rejection of formalism. Human institutions are imperfect, and formalist rules sometimes may be the best we can do. Formalism's moral costs can be outweighed by other benefits. But if we should not reject formalism out of hand, neither should we be sanguine about trumpeting the moral splendors of formalism over the untidy pragmatism of its opponents.

Formalism is a word with many shades of meaning. Before turning to Alexander's and Katz's views, we need at least a working definition. Fred Schauer's concept of rule-based decisionmaking is a good starting point. For Schauer, the key to formalism is a determination to ignore the inevitable misfit between a rule and its background justifications, "resisting efforts to pierce it in the service of those justifications." A simple example is provided by age limits, which are enforced without regard to the particulars of individual cases, such as whether a given twelve year old could in fact drive or vote as well as most adults. It is hard to quarrel with Schauer's view that such rules are a common and legitimate part of our legal system, or with his observation that judges often seem to adopt this approach to decisionmaking unless application of a rule seems seriously awry.?

Schauer's version of formalism mutes the decisionmaker's moral dilemma by making rules only presumptively binding. ${ }^{8}$ But other formalists would go farther, by identifying judicial decisions as legitimate only to the extent that they strictly follow the rules laid down. For instance, Judge Easterbrook says, "the judicial branch serves best by enforcing enacted words rather than unen-

s Larry Alexander "With Me, It's All er Nuthin": Formalism in Law and Morality, 66 U Chi I Rev 530, 531 (1999); Leo Katz, Form and Substance in Law and Morality, 66 U Chi L Rev 566, 566-67 (1999).

B Frederick Schauer, Rules and the Rule of Law, 14 Harv J I \& Pub Pol 645, 649 (1991).

7 Id at $657-63,676-91$.

- Id at 678-79. 
acted (more likely, imagined) intents, purposes, and wills." $\mathrm{He}$ asks whether anyone would "surrender power to someone who can be neither removed from office nor disciplined, unless that power was constrained," and answers that the "constraint is the promise to abide by the rules in place." ists (such as Judge Easterbrook or Justice Scalia), the rule of law is, essentially, the law of rules. ${ }^{11}$

Suppose, then, that Shylock sues for specific performance, the only defense being that collection of the pound of flesh would violate the Venetian law against shedding blood. But Shylock then proposes use of the red-hot knife. For Schauer, the case may not pose a dilemma, since he is not wedded to strictly rule-based decisions in all cases. Thus, he could rule against Shylock without violating his credo. But a strict formalist like Easterbrook is fully committed to decision by rule, so this solution to Shylock's dilemma poses a genuine problem for him. Sometimes, he may be able to find a formalist escape hatch. He might find recourse in some other legal rules, perhaps including meta-rules allowing rejection of literal meaning on certain designated occasions. Or, when push comes to shove, he might abandon formalism in the name of morality, as Scalia hints that he might do in similar circumstances. ${ }^{12}$ But the question is whether the strict formalist can consistently avoid paying a moral cost if he remains true to his jurisprudential position. My thesis is that he cannot.

\section{THE Formalist's MORAL DILEMMA}

Larry Alexander's contribution to this Symposium makes two basic arguments. ${ }^{13}$ The first is that law is "essentially formalistic"-only truly law-like to the extent it is made up of rules rather than standards. The second is that formalistic law presents an inescapable dilemma. Although the first of these arguments contains an interesting insight, I remain unconvinced. The second argument, however, makes an important point about the tension between formalism and certain ethical principles.

By formalism, Alexander seems to mean much the same as what I have called strict formalism, or as he says, "adherence to a norm's prescription without regard to the background reasons the

- Frank H. Easterbrook, Textualism and the Dead Hand, 66 Geo Wash L Rev 1119, 1120 (1998).

${ }^{10}$ Id at 1122 .

"Antonin Scalia, The Rule of Law as a Law of Rules, 56 U Chi L Rev 1175, 1178-81 (1989) (advocating the use of rules in judicial decisionmaking to further predictability).

${ }^{12}$ Antonin Scalia, Originalism: The Lesser Evil, 57 U Cin I Rev 849, 864 (1989).

${ }^{13}$ Alexander, 66 U Chi L Rev at 530 (cited in note 5). 
norm is meant to serve."14 Thus, a "formalist looks to the form of a prescription - that it is contained in an authoritative rule-rather than the substantive end or ends that it was meant to achieve," which in the particular case it may fail to do. ${ }^{15}$ The formalist would presumably look at the form of the Venetian rule-a prohibition on releases of circulatory fluid-rather than its goal, the prevention of acts of violence. In Alexander's view, then, Venice presumably could claim to enjoy the rule of law if, and only if, its judges were willing to allow Shylock the use of the red-hot knife.

This claim does not lack for boldness. In my own view, at least, Alexander fails to justify it. His argument runs more or less as follows. Imagine a community in which everyone operates in good faith and shares the same basic moral commitments. Even in such a community, there will be disagreements about the specific applications of moral norms. The best way to resolve these disputes is to recognize a neutral arbiter, whose decisions will eventually create a body of binding applications of the norms. But those decisions can only help resolve moral disputes if they can be understood and applied without reaching behind them for their moral wellsprings. Otherwise, people who have moral disagreements won't be able to agree on the meaning or validity of the rulings either. ${ }^{16}$ Thus, law can serve an important coordination function by providing a form of authoritative settlement. But that coordination function requires what Alexander calls "serious rules." ${ }^{17}$ Such rules ideally should be fully determinate, so that regardless of their moral disagreements, "everyone in the community will agree about what the rules require in every case." 18 Only if people with divergent moral views can agree on the meaning of a rule can the rule perform this coordination function.

By emphasizing this authoritative settlement function, Alexander makes a significant point about the need for rules, even under nearly ideal circumstances of social consensus. But it seems to me his argument falls short in at least two ways. First, it ignores the possibility that a ruling might in fact eliminate the moral dispute by persuading at least one of the parties to change her moral views. ${ }^{19}$ So, after the fact, there may be no moral disagreement in the community regarding the particular issue, and

\footnotetext{
${ }^{14}$ Id at 531.

${ }^{15}$ Id at 531.

${ }^{16}$ Id at 532.

${ }^{17}$ Id at 541.

${ }^{19}$ Id at 544.

${ }^{19}$ This function might be clearest in a legal system that lacks strong enforcement mechanisms, such as Talmudic law or international law.
} 
hence no need to announce a "morally opaque" rule. ${ }^{20}$ Second, and more importantly, the argument assumes that law's coordinating function is its only function. But law has many functions besides providing authoritative settlements for disputes in Alexander's community of virtual saints. Perhaps the most obvious is that it deters nonsaints from doing bad things. But it also encourages negotiation and voluntary dispute resolution, and it provides redress after a wrong is done. It is not obvious that these other functions require rule-based decisionmaking. Thus, although $\mathrm{Al}-$ exander has usefully highlighted an important and sometimes neglected function of law, a considerable gap remains between this insight and his sweeping conclusion.

For present purposes, however, Alexander's failure to establish that all law is essentially formalistic is irrelevant. We both agree that at least some law is formalistic, which is enough to make his argument about the formalist moral dilemma important. That argument is both simple and powerful. Rules oversimplify in the interest of guiding future behavior effectively. Consequently, any rule inevitably falls short in some ways and overshoots in others when compared to the decisions we would make if we were trying to do exact justice in every case. If we apply the rule when it does not really match a case's equities, we do an injustice in a particular case in order better to do justice in the long run. But this violates what Alexander views as the core of deontological ethics: that we are not allowed to break the commands of justice today as to one person in order to attain beneficial consequences later for others.

In particular, Alexander says, society cannot appropriate the rights of an individual in order to make itself better off. But this is just what we are doing when, for example, we allow use of the red-hot knife, despite our moral qualms, because of the need to have determinate rules and to limit judicial discretion. ${ }^{21}$ Or, to take a more historically realistic example, it was simply wrong for any judge to order the return of an escaped slave, the Fugitive Slave Clause and the need for "authoritative settlement" notwithstanding. In both situations the legal system uses one person as a mere instrument in order to attain greater social goals, and it is this that deontological ethics in general condemns.

\footnotetext{
${ }^{20}$ Of course, to the extent that we are skeptics about the idea of resolving moral disputes through persuasion, we are entitled to doubt the importance of this possibility. But since Alexander himself is trying to persuade us of a moral position through an intricate argument, he probably cannot consistently embrace this skepticism.

${ }^{21}$ Alexander, $66 \mathrm{U}$ Chi L Rev at 559-61 (cited in note 5).
} 
There is no such thing as a foolproof philosophical argument. This one is surely no exception. Nevertheless, Alexander's argument poses a serious challenge for those who argue that only formalism can give law legitimacy. For if he is right, whatever legitimacy strict formalism gives with one hand, it necessarily takes away with the other.

\section{FORMALISM AND MORAL CHARACTER}

Leo Katz's contribution begins with a striking question: "When lawyers do what lawyers do best are they being wicked?"2 He has famously argued that the whole point of having moral and legal rules is that they are rules, which means that if you don't break any of the rules, you haven't done anything wrong. ${ }^{23}$ His position is illustrated by a series of vivid hypotheticals. Consider the uptight would-be murderer Alexander dubs "the Cowardly Jackal."24 The Cowardly Jackal wants to commit a murder but is unwilling to commit an intentional assault. Consequently, he is reduced to driving by his enemy's house day after day, hoping the enemy will step in front of the car too quickly for him to be able to stop. ${ }^{25}$

The Cowardly Jackal exemplifies Katz's thesis that the morality of actions depends on whether the means used to accomplish them comply with certain rules, not on their ultimate purpose. An even better example is provided by a character in a murder mystery: This character is a transplant surgeon who is deeply distressed at the shortage of useable organs. As a devout Christian, obviously he could not commit murder in order to obtain organs. Consequently, he dedicates his time and money to encouraging motorcyclists to drive without helmets and lobbying against helmet laws. ${ }^{26}$

Katz has defended the morality of ingenious schemes such as these. ${ }^{27}$ In Form and Substance in Law and Morality, Katz attempts to reply to his critics, in the process elaborating his views (or perhaps shifting them slightly) ${ }^{28}$ It is not my purpose, however, to interpose myself in the battle between Katz and his crit-

\footnotetext{
22 Katz, 66 U Chi L Rev at 566 (cited in note 5).

${ }^{25}$ Leo Katz, Ill-Gotten Gains: Evasion, Blackmail, Fraud, and Kindred Puzzles of the Law (Chicago 1996). Or at least, this is the closest I can come to summarizing Katz's IllGotten Gains in a single sentence.

${ }^{24}$ Alexander, $66 \mathrm{U} \mathrm{Chi} \mathrm{L}$ Rev at 560-61 (cited in note 5).

${ }^{25} \mathrm{Id}$ at 561 .

${ }_{28}$ Faye Kellerman, Prayers for the Dead 340-41 (Avon 1997).

${ }^{27} \mathrm{Katz}, \mathrm{Ill}$-Gotten Gains (cited in note 23).

${ }^{23} \mathrm{Katz}, 66 \mathrm{U}$ Chi L Rev 566 (cited in note 5).
} 
ics. As with Alexander, the full scope of Katz's thesis is unnecessary for my own argument. What I do need is one piece of his argument and one concession he now seems to make about its limits. The core of his argument is that rules of conduct define prohibited actions, rather than identify goals that individuals must seek. For instance, suppose that the rule against murder were not a ban on certain kinds of prohibited actions, but were rather about avoiding increased human mortality. In that case, we wouldn't have a rule of conduct at all, but rather a general ethical injunction to maximize expected mortality. That is, we would have what is commonly called a standard rather than a rule. Katz seems to believe that the essential character of all moral and legal rules is a focus on specific actions rather than general goals, meaning we adhere to rules of conduct rather than to standards relating to societal objectives.

Assuming at least some rules are formalistic in this sense, Katz is clearly correct that the validity of an action cannot always depend on the nature of the actor's goal. It must sometimes be possible to pursue a goal legitimately through one action, even though another way to do so is forbidden. It is illegal to drive from 2000 Portland Avenue south to 2100 Portland, because Portland Avenue is one-way, but it is neither morally nor legally questionable to complete the same trip by driving around the block. The permissibility of an action under this kind of rule depends on the path taken to the goal, not on the goal itself.

The problem, as Katz recognizes, is that some efforts to exploit the "path dependency" of rules seem much more troublesome. Although he still believes that shrewd strategic manipulation does not violate moral or legal rules, he now seems to concede that exploitation of path dependency can nevertheless raise a moral problem:

It might be possible for me to inflict great physical and mental distress on you by simply sufficiently upsetting you about something I am entitled to do. ... It seems the essence of liberty that there are a few things that I can do quite without regard to how upsetting you find them. Thus, if I can succeed in rearranging some harm that I was about to inflict on you so that it is inflicted through my exploitation of some liberty that I have, then I have somehow gotten the moral benefit of my strategy. But I am still eligible for condemnation, just not 
the kind of condemnation that is required for criminal punishment. ${ }^{29}$

Or, in more ordinary language, although I may not have broken any rules, I may still be a really rotten person.

There is a more general point here. A formalistic system puts a great premium on people (particularly lawyers) who are able to invent clever ways to manipulate the rules to produce desired outcomes. Of course, the more counterintuitive the outcome-the more it violates what seems to be the purpose of the rule or runs against social norms-the harder this task becomes and the more valuable are the skills involved. Just as Trollope's lawyer Mr. Chaffanbrass found it beneath his dignity to defend an innocent client, ${ }^{30}$ so too the lawyer of truly Katzian ingenuity will only be needed when some incredibly intricate maneuver is needed to defeat the plain intent of the law.

This kind of work is not necessarily immoral or even amoral. It may sometimes be socially indispensable. Indeed, some formalistic legal systems have relied heavily on such rule manipulation simply to keep society functioning. For example, in order to make land marketable, medieval lawyers invented marvelously complex transactions, using elaborate fictional lawsuits to clear titles or transfer property. ${ }^{31}$ But as Katz recognizes, legal rules often do track society's moral understandings. In those situations, the really clever lawyer looks more than a little like a refugee from one of Katz's hypotheticals, or like the fictional transplant surgeon who encourages people to ride motorcycles without helmets. Not immoral, necessarily, but (like many of Katz's examples), not someone whose good character you would want to vouch for. As another character says of the transplant surgeon's conduct, "I don't know if it's illegal . . . but preying on victims like that is major league creepy." ${ }^{\prime 2}$

Id at 593.

${ }^{30}$ Anthony Trollope, The Three Clerks 481-82 (Oxford 1929) (first published 1858):

Let others, the young lads and spooneys of his profession, undertake the milk-andwater work of defending injured innocence; it is all but an insult to his practised ingenuity to invite his assistance to such tasteless business. . . . Let him, by the use of his high art, rescue from the gallows and turn loose upon the world the wretch whose hands are reeking with the blood of father, mother, wife, and brother, and you may see Mr. Chaffanbrass, elated with conscious worth, rub his happy hands with infinite complacency.

s1 See A.W.B. Simpson, A History of the Land Law 128-37, 188-90, 232-41 (Oxford 2d ed 1986) (describing the complex property transactions that took place in the middle ages).

${ }^{32}$ Kellerman, Prayers at 342 (cited in note 26). This strikes me as an apt description of many of Katz's protagonists. 
If Katz's deontological ethics, like Venetian law, merely forbade the shedding of blood, then he would be unable to block Shylock's use of the red-hot knife (though he might view it as subject to some form of milder condemnation). Katz, of course, would actually disallow the red-hot knife because his moral and legal code says something like "thou shalt not kill" rather than "thou shalt not shed blood." But he would no doubt allow Shylock to devise some other brilliant scheme in which the result is that Antonio does lose a pound of flesh. For example, knowing that Antonio cannot resist pâté, Shylock could arrange for the delivery of a pound a day, until Antonio's inevitable coronary problems require a heart transplant-which will, however, do Antonio no good, since Shylock will continue to ply him with pâté. (Or maybe he could persuade Antonio to ride a motorcycle without a helmet.) This might not make Shylock a murderer, but it would make him a nasty, calculating person. One moral risk of formalism is that it encourages and rewards this kind of nastiness. The lawyer who spends his days devising sly tax avoidance techniques may come to approach other parts of life with similar calculation. Formalism, in other words, may be bad for your character, if taken to excess.

\section{A CODICIL FOR CONSEQUENTIALISTS}

Alexander and Katz, in my view, expose some genuine moral difficulties with formalism. Although they claim formalism to be essential to certain kinds of rules (either moral or legal), it is not necessary to accept their versions of strict formalism in order to adopt their conclusions about the moral costs of formalism. Similarly, the problems they identify are matters for real concern, even for consequentalists who do not share their attachment to deontological ethics.

Of course, it is a truism that rules are likely to be over and underinclusive, so that their bluntness must be traded off against their potentially greater clarity and ease of application. But consequentialists have not, I think, sufficiently considered the effects of formalism on the actors within the system. One consequence is that judges are required to approve or even mandate conduct that offends deeply held moral norms. Those norms may be irrational, or they may be psychological adaptations derived from some socially beneficial conduct. Nevertheless, they are real, and forcing judges to violate them is unpleasant and costly. Moreover, it creates an agency problem, since judges will in fact be reluctant to approve these tactics, which means that formal rules may lack credibility. A contract that calls for use of a red-hot knife may not 
ultimately be enforced by a Venetian court, so the rule purportedly requiring enforcement of the contract is less "rule-like" than it appears. And the more formalism does require judges to enforce such contracts, the more courts will be resented, and the more they will attract primarily the callous or the cruel, who are not likely to be ideal judges in other respects. In other words, moral costs are also social costs, in one form or another.

Thus, there are real costs to formalism, which should help warn us against a rush toward formalism for its own sake. It is too easy to celebrate the virtues of clear rules if we lose track of their defects. But neither should we sentimentalize. A certain amount of formalism is unavoidable. As a result, the kind of moral risk dramatized by the story of the red-hot knife may be difficult to eliminate from any legal system. ${ }^{33}$

\footnotetext{
3 Examples in our own legal system might include a judge who is compelled to dismiss a meritorious case because of a jurisdictional or procedural rule that serves no societal purpose in that particular case, or who is compelled to enter a draconian mandatory sentence against a defendant whose unusual circumstances render the sentence unjust.
} 